\title{
Studies on Improved Amylases Developed by Protoplast Fusion of Aspergillus species
}

\author{
Tolulope Modupe Adeleye ${ }^{1 *}$, Sharafadeen Olateju Kareem ${ }^{1}$, Bankole Mobolaji Olufunmilayo ${ }^{1}$, Olusegun Atanda ${ }^{3}$, \\ Michael Bamitale Osho ${ }^{3}$, and Olawale Dairo ${ }^{2}$ \\ ${ }^{1}$ Department of Microbiology, College of Biosciences, Federal University of Agriculture Abeokuta, P.M.B. 2240, Abeokuta, Nigeria \\ ${ }^{2}$ Department of Agricultural Engineering, College of Engineering, Federal University of Agriculture Abeokuta, P.M.B. 2240, Abeokuta, Nigeria \\ ${ }^{3}$ Department of Biological Sciences, College of Natural and Applied Sciences, McPherson University, Km 96, Lagos-Ibadan Expressway, Seriki \\ Sotayo, P.M.B. 2094, Abeokuta, Nigeria
}

Received: March 31, 2020 / Revised: June 22, 2020 / Accepted: June 29, 2020

\begin{abstract}
Improved amylases were developed from protoplast fusants of two amylase-producing Aspergillus species. Twenty regenerated fusants were screened for amylase production using Remazol Brilliant Blue agar. Crude enzyme extracts produced by solid state fermentation of rice bran were assayed for activity. Three variable factors (temperature, $\mathrm{pH}$ and enzyme type) were optimized to increase the amylase activity of the parents and selected fusants using rice bran medium and solid state fermentation. Analysis of this optimization was completed using the Central Composite Design (CCD) of the Response Surface Methodology (RSM). Amylase activity assays conducted at room temperature and $80^{\circ} \mathrm{C}$ demonstrated that Aspergillus designates, T5 $(920.21 \mathrm{U} / \mathrm{ml}, 966.67 \mathrm{U} / \mathrm{ml}), \mathrm{T} 13(430 \mathrm{U} / \mathrm{ml}, 1011.11 \mathrm{U} / \mathrm{ml})$ and T14 (500.63 U/ml, $1012.00 \mathrm{U} / \mathrm{ml})$ all exhibited improved function making them the preferred fusants. Amylases produced from these fusants were observed to be active over the entire $\mathrm{pH}$ range evaluated in this study. Fusants T5 and T14 demonstrated optimal activity under acidic and alkaline conditions, respectively. Fusants T13 and T14 produced the most amylase at $72 \mathrm{~h}$ while parents TA, TC and fusant T5 produced the most amylase after $96 \mathrm{~h}$ of incubation. Response surface methodology examinations revealed that the enzyme from fusant T5 was the optimal enzyme demonstrating the highest activity $(1055.17 \mathrm{U} / \mathrm{ml})$ at $\mathrm{pH} 4$ and a temperature of $40^{\circ} \mathrm{C}$. This enzyme lost activity with further increases in temperature. Starch hydrolysis using fusant T5 gave the highest yield of glucose $(1.6158 \mathrm{~g} / 100 \mathrm{ml})$. The significant activities of the selected fusants at $28 \pm 2{ }^{\circ} \mathrm{C}$ and $80^{\circ} \mathrm{C}$ and the higher sugar yields from cassava starch hydrolysis over their parental strains indicate that it is possible to improve amylase activity using the protoplast fusion technique.
\end{abstract}

Keywords: Protoplast fusion, Aspergillus species, amylase, solid state fermentation, optimization, response surface methodology

\section{Introduction}

Amylases from microbial sources have become the most demanded and important enzymes in present day biotechnology meeting industrial needs [1]. Most of the developing countries have concentrated studies on fungal amylases mainly from Aspergillus and Rhizopus species

\footnotetext{
*Corresponding author

Tel: +234-8038205666

E-mail: tolulopemodupeade@gmail.com
}

probably because of their ubiquitous and nutritionally non-fastidious nature which favors a growing economy [2]. The optimum conditions for amylase activities have been studied by various researchers [3, 4]. The applications and uses of amylases in the industries have been challenged by the poor stability of enzymes being used, which results in limited glucose yields and the formation of condensation products (mainly $\alpha-1,6$-linked isomaltoseoligosaccharides), during prolonged hydrolysis of $\alpha$ 1,6 glycosidic bonds in starch. The conventional biocon- 
version of starch to glucose and other oligosaccharides involves a two-step process which are; liquefaction and saccharification. The $\alpha$-amylase is introduced at a high temperature $\left(80-95^{\circ} \mathrm{C}\right)$ and $\mathrm{pH} 6.0$ during the process of liquefaction which is then followed by saccharification process using glucoamylase at $\mathrm{pH} 4.5-5.0$ and at temperature ranges of $40^{\circ} \mathrm{C}$ and $60^{\circ} \mathrm{C}$ [5]. The enzymatic hydrolysis of starch is energy intensive, time consuming, and therefore has high cost implications which is as a result of the need to lower process temperature and to bridge the $\mathrm{pH}$ differential between the two enzymes being used [6]. Strain improvement programmes can however, help to bridge this gap.

Genetic manipulation techniques have made possible improved characteristics of microbial amylases such as thermostability and wide $\mathrm{pH}$ range of activity [6, 7]. An example of such important technique in physiological and genetic research is fungal protoplast fusion. The genetic recombination of traits in filamentous fungi that lack the capacity for sexual reproduction can be successfully achieved through fusion of protoplasts [8, 9]. The technique of protoplast fusion has been used for improvement of industrial strains for enzymes production $[10,11]$.

Production of amylases is not commercialized yet and therefore they have become too expensive for amylaseutilizing industries Nigeria [12]. However, fungal organisms which are known for their ability to synthesize these enzymes are readily available in our environment. After isolation, there is a need for the exploration of the production efficiencies of these organisms by studying the best conditions for a higher productivity. In other words, to achieve a successful commercialization of amylase production, optimization of cultural conditions is of uncompromising importance. Studies on optimization reveal the cultural conditions under which the microorganisms will grow luxuriantly, produce amylase in maximum amounts and improved activities. Factors such as incubation period, temperature and $\mathrm{pH}$ are important for the better enzyme yield and activity. These factors have been found to determine the growth of the enzyme producing microorganisms as well as the extent to which they can produce amylase [13-15].

An effective experimental statistical technique such as Response Surface Methodology (RSM) provides an alternative to the conventional approach in many biotechno- logical processes. The RSM reveals the correlations between the factors and responses as well as predicting the optimum levels of each factor employed [16]. As an empirical modeling system, the RSM helps to develop, optimize and assess the relationships between the independent variables and the response(s) as it defines the effect of each independent variable or their combinations in complex processes [17, 18]. Using the RSM, industrial processes can be validated on a large scale [19].

The aim of this study was to access the effect of protoplast fusion technique in the development of improved amylases from Aspergillus spp. The effect of incubation period was studied while the response surface methodology was employed to optimize conditions of temperature, $\mathrm{pH}$ and enzyme type for activities of amylases from parents and selected fusants.

\section{Materials and Methods}

\section{Development of Improved Amylases}

Improved amylase-producing Aspergillus species were developed by the protoplast fusion technique. Spore suspensions for each of the two amylase-producing Aspergillus species were prepared from cultures obtained from the culture collection centre, department of Microbiology, Federal University of Agriculture Abeokuta (FUNAAB), Nigeria.

Protoplast fusion. Cells taken from mid exponential phase were harvested from the cultures of the parent Aspergillus species which had been grown in a $500 \mathrm{ml}$ flask containing $50 \mathrm{ml}$ Potato dextrose broth at $30^{\circ} \mathrm{C}$. $5 \mathrm{ml}$ of the broth was withdrawn and centrifuged at $500 \mathrm{~g}$ for $20 \mathrm{~min}$ at $4^{\circ} \mathrm{C}$. The sediment was washed with $5 \mathrm{ml}$ of $0.1 \mathrm{M}$ potassium phosphate buffer ( $\mathrm{pH}$ 6.4). The cell suspension was centrifuged to get the pellet and then resuspended in the protoplasting buffer. Lysozyme $\left(6 \mathrm{mg} / \mathrm{ml}\right.$ ) was added at $30^{\circ} \mathrm{C}$ and incubated for $3 \mathrm{~h}$. The mixture was centrifuged at $500 \mathrm{~g}$ for $10 \mathrm{~min}$ at $28^{\circ} \mathrm{C} .1 \mathrm{ml}$ of mixture containing 35\% PEG, $10 \mathrm{mM} \mathrm{CaCl}_{2}$ and $0.5 \mathrm{M}$ sorbitol was added to the pellet and incubated at room temperature $\left(28 \pm 2^{\circ} \mathrm{C}\right)$ for $30 \mathrm{~min}$. The suspension was diluted with $0.1 \mathrm{M}$ phosphate buffer of $\mathrm{pH} 6.5$ (1:1 ratio). One millimeter of the diluted suspension was mixed with $10 \mathrm{ml}$ of the regeneration medium SDA (Sabouraud Dextrose Agar) containing 0.8 M sorbitol, 
and poured into sterile petri-dishes. Plates were incubated at $30^{\circ} \mathrm{C}$ for $3-7$ days until visible regenerated colonies emerged. The regenerated fusants were screened for amylolytic activities on the Remazol Brilliant Blue (RBB) agar, using the methods as previously reported [20]. The plate medium was made up of nutrient agar containing RBB-starch (0.2\% Remazol Brillant BlueStarch). The medium was autoclaved at $121^{\circ} \mathrm{C}$ for $15 \mathrm{~min}$ at a $\mathrm{pH}$ of $4.5 .0 .1 \mathrm{ml}$ of the spore suspension of the Aspergillus species were inoculated on the RBB-starch agar and incubated at $30^{\circ} \mathrm{C}$ for $48 \mathrm{~h}$. Amylase production was detected by the disappearance of the color of the blue starch around microbial colonies. The clear zones were measured with vennier calipers by taking two perpendicular diameter measurements. Fusant colonies showing wider diameters than the parent Aspergillus were selected for further assay of amylase activity. Pure cultures were maintained on SDA slants at $4^{\circ} \mathrm{C}$ and subcultured bi-monthly.

\section{Screening for improved amylase activities in fusant isolates}

The parent and selected fusants were grown on rice bran solid media for amylase production in solid state fermentation (SSF) using standard methods [21]. Moldy bran cultures were harvested and mixed with acetate buffer $\mathrm{pH} 6.5(1: 10 \mathrm{w} / \mathrm{v})$. Assay for amylase activity was done at $80^{\circ} \mathrm{C}$ and room temperature $\left(28 \pm 2^{\circ} \mathrm{C}\right)$. Amylase activity was determined using dinitrosalicylic acid (DNSA) method and glucose was used as the standard. One unit of enzyme activity was defined as the amount of enzyme which liberates 1 micromole of glucose from starch in a $1 \mathrm{ml}$ reaction mixture at $60^{\circ} \mathrm{C}$ for $1 \mathrm{~h}$. Values below $400 \mathrm{U} / \mathrm{ml}$ were regarded as "not significant". Fusants with higher amylase activity than parent strains at $80^{\circ} \mathrm{C}$ and at room temperature were selected for further studies, molecular characterization and identification.

\section{Molecular characterization of selected isolates}

Genomic DNA for each of parent and fusant isolate was extracted using DNeasy Plant Mini Kit (Qiagen, Germany) according to the manufacturer's instructions. Quality assessment of DNA was performed by agarose gel electrophoresis and Qubit Fluorometer (Invitrogen, Germany). The Internal Transcribed Spacer (ITS) region which is a universal DNA barcode marker for fungi was used as primer for the PCR analysis. The 5.8S region sequences of the ITS 1 and ITS 4 (for the forward and backward reactions, respectively) regions were used.

ITS 1: 5’ TCC GTA GGT GAA CCT GCG G 3'

ITS 4: 5' TCC TCC GCT TAT TGA TAT GC 3'

Conditions for the polymerase chain reaction included a cycle of initial denaturation at $94^{\circ} \mathrm{C}$ for $5 \mathrm{~min}$, followed by 35 cycles of each cycle comprising of $30 \mathrm{sec}$ denaturation at $94^{\circ} \mathrm{C}, 30 \mathrm{sec}$ annealing of primer at $55^{\circ} \mathrm{C}, 1.5 \mathrm{~min}$ extension at $72^{\circ} \mathrm{C}$ and a final extension for $7 \mathrm{~min}$ at $72^{\circ} \mathrm{C}$. The nucleotide sequences of 5.8S-ITS region were determined using the sequencer (Gene analyzer 3121). The deduced sequence was aligned using Molecular Evolutionary Genetics Analysis (MEGA) version 5.10 [22]. The forward and reverse sequences were checked and edited manually when needed. A consensus sequence was generated from each alignment made. The sequencing data were compared against the Gene Bank database (http:// www.ncbi.nlm.nih.gov/BLAST/), where a nucleotide blast program was chosen to identify the homology between the PCR fragments and the sequences on the Gene Bank database. A phylogenetic tree was also constructed and the variations in the branch length were determined.

\section{Effect of incubation period on amylase production}

Effect of incubation on amylase production was determined by measuring the amylase activities of isolates 12 hourly. Cultures of parent and fusant isolates were grown on rice bran medium at $28 \pm 2^{\circ} \mathrm{C}$ for $120 \mathrm{~h}$ in a rotary shaker at $800 \mathrm{~g}$. Samples were taken 12 hourly and assayed in $0.01 \mathrm{M}$ phosphate buffer $\mathrm{pH} 6$ at $55^{\circ} \mathrm{C}$. Amylase activity was measured using standard spectrophotometric methods. The reaction mixture for enzyme assay contained crude enzyme extract, substrate (1\% starch w/v) and 3-5, dinitrosalicyclic acid as coupling reagent.

\section{Response surface methodology for optimization studies of Amylase Activity}

The Central Composite Design (CCD) of the Response Surface Methodology (RSM) was used for this study. The variables assessed were temperature $\left(40-80^{\circ} \mathrm{C}\right), \mathrm{pH}(4-$ 8 ) and enzyme type (1-5). Optimization of the experimental data obtained was performed by RSM to fit the data into a second-order polynomial equation of the form shown in equation (1). 


$$
Y=\beta_{0}+\sum_{i=1}^{k} \beta_{i} X_{i}+\sum_{i=1}^{k} \beta_{i i} X_{i}+\sum \sum_{i<j=1}^{k} \beta_{i j} X_{i} X_{j}
$$

where $\mathrm{Y}$ is the response (amylase activity), $k$ represents the number of factors (3) studied, $X_{i}, X_{j}(\mathrm{i}=1,4$; $\mathrm{j}=1,4 ; \mathrm{i} \neq \mathrm{j}$ represents coded independent variables) are the model coefficients, $\beta_{\mathrm{o}}, \beta_{\mathrm{i}}, \beta_{\mathrm{ii}}$ and $\beta_{\mathrm{ij}}$ are intercepts, linear, quadratic and interaction coefficients respectively.

Effect of variables factors on activity of amylases from parental and fusant Aspergillus species. The effect of each of $\mathrm{pH}(4-8)$ and temperature $\left(40-80^{\circ} \mathrm{C}\right)$ was determined on the amylase activities of selected fusants and parent Aspergillus. The relative enzyme activity was determined using cassava starch $(5 \% \mathrm{w} / \mathrm{v})$ as a substrate [23]. Briefly, $1 \mathrm{ml}$ of starch in $50 \mathrm{mM}$ phosphate buffer ( $\mathrm{pH} 4-$ 8) with $1 \mathrm{~g}$ moldy bran was mixed and incubated at $60^{\circ} \mathrm{C}$ for $30 \mathrm{~min}$. The enzymatic reaction was stopped by the addition of $2 \mathrm{ml}$ of DNSA. After $5 \mathrm{~min}$ of heating at $100^{\circ} \mathrm{C}$, the reaction mixture was chilled on ice for $2 \mathrm{~min}$ and then diluted to $5 \mathrm{ml}$ by adding distilled water. The absorbance measurements were performed at $530 \mathrm{~nm}$ using spectrophotometer (Shimadzu UV-1 700, Japan). Enzyme activity was calculated using a calibration curve prepared with D-glucose as a standard by following the same procedure described above.

\section{Statistical analysis}

Five different levels used to study the independent variables as stated in section 2.5. Enzyme activity was taken as a dependent variable (Y). The Design Expert 9.0.3 statistical software (Stat-Ease) was used to provide the required experimental runs for all the variables and levels. The statistical approach using CCD (Central Composite Design) developed by the Design Expert software was used to generate a set of 85 experimental runs. A quadratic polynomial regression model was used to describe the relationship between dependent and independent variables. Analysis of Variance (ANOVA) of values obtained from the quadratic polynomial equation was used to describe the model and also to determine significant terms.

\section{Effect of amylases from parents and fusant Aspergillus on starch hydrolysis}

The effect of amylases on starch hydrolysis was stud- ied by measuring the ribose sugars present in starch hydrolyzed by parent and fusant Aspergillus using a modified gas chromatographic as previously described [24]. Partially purified enzyme extracts were used in hydrolysis of cassava $(5 \% \mathrm{w} / \mathrm{v})$ starch at individual optimum $\mathrm{pH}$ and temperature. $5 \mathrm{ml}$ of sample was heated at $60^{\circ} \mathrm{C}$ with $50 \mathrm{ml}$ of $80 \%$ ethyl-alcohol and the mixture was centrifuged. $10 \mathrm{ml}$ of the extract was heated in boiling water for $4 \mathrm{~min}$ to inactivate the enzymes and protein was precipitated and clarified by centrifugation. The residual starch was removed by centrifuging at $500 \mathrm{~g}$ for $15 \mathrm{~min} .0 .1 \mathrm{ml}$ of the filtrate was placed in $5 \mathrm{ml}$ vial and dried at room temperature with nitrogen steam. The extract was derivatised by the addition of $0.05 \mathrm{ml}$ mixture of pyridine: hexamethyldisilane:trimethylchlorosilane in the ratio of 10:2:1. The derivatization was completed in $2 \mathrm{~h}$. The derivatised extract was concentrated to $1 \mathrm{ml}$ in the vial for the gas chromatography analysis. $1.0 \mu \mathrm{l}$ of extract was injected into the injection port of the column for the sugar analysis.

\section{Results}

\section{Screening for amylase production by regenerated fusants Aspergillus species}

Table 1 shows zones of clearing of 7 randomly selected regenerated fusants and parent isolates, on RBB agar and also the individual amylase activities at $80^{\circ} \mathrm{C}$ and at room temperature. Fusants, T15, T13 and the parent, TC had the least diameter of clearing $(2.0 \mathrm{~cm})$ while

Table 1. Screening for amylase production by parent and fusant isolates of Aspergillus species.

\begin{tabular}{cccc}
\hline Isolates & $\begin{array}{c}\text { Diameter of } \\
\text { Clearing on } \\
\text { RBB }(\mathrm{cm})\end{array}$ & $\begin{array}{c}\text { Activity at } 28 \pm 2{ }^{\circ} \mathrm{C} \\
(\mathrm{U} / \mathrm{ml}) \\
(\mathrm{mean} \pm \mathrm{SE})\end{array}$ & $\begin{array}{c}\text { Activity at } 80{ }^{\circ} \mathrm{C} \\
(\mathrm{U} / \mathrm{ml}) \\
(\mathrm{mean} \pm \mathrm{SE})\end{array}$ \\
\hline PARENT A & 3.0 & $586.14 \pm 0.49$ & $933.33 \pm 1.67$ \\
PARENT C & 2.0 & $332.00 \pm 0.56$ & $420.00 \pm 0.50$ \\
${ }^{*}$ T5 & 4.0 & $920.21 \pm 0.72$ & $966.67 \pm 1.34$ \\
${ }^{*}$ T13 & 2.0 & $430.00 \pm 0.00$ & $1011.11 \pm 5.56$ \\
${ }^{*}$ T14 & 2.2 & $500.63 \pm 0.74$ & $1012.16 \pm 0.58$ \\
T15 & 2.0 & $420.32 \pm 0.34$ & $920.11 \pm 4.56$ \\
T16 & 2.1 & $467.12 \pm 1.05$ & $910.00 \pm 0.00$ \\
T17 & 2.0 & $400.00 \pm 0.59$ & $700.77 \pm 0.12$ \\
T18 & 2.1 & $300.56 \pm 0.22$ & $710.16 \pm 0.42$ \\
\hline
\end{tabular}

KEY*-Selected fusants. 
fusants, T14, T17, T16 and T18 had a slightly wider clearing $(2.1 \mathrm{~cm})$. Parent TA had a $3.0 \mathrm{~cm}$ diameter of clearing. Fusant, T5 showed a clearing zone of $4.0 \mathrm{~cm}$ which is wider than that of both parents and other selected fusants. Activity at room temperature $\left(28 \pm 2^{\circ} \mathrm{C}\right)$ was highest in T5 $(920.21 \mathrm{U} / \mathrm{ml})$ and lowest in T18 (300.56 U/ml). At $80^{\circ} \mathrm{C}$, all the fusant isolates and one of the parents (TA) had high amylase activity. At room temperature, only T5 had amylase activity higher than both parents (TA and TC). At $80^{\circ} \mathrm{C}$, improved amylase activity over the parents was observed in T5 (966.67 U/ $\mathrm{ml})$, T13 (1011.11 U/ml) and T14 (1012.16 U/ml) while parent, TC, showed the least activity $(420 \mathrm{U} / \mathrm{ml})$. Fusants T5, T13 and T14 were thus selected for further comparative studies with the parents, TA and TC.

\section{Molecular identification and phylogenetic tree represen- tation of sequences}

Results of the molecular characterization of parental and selected fusants are represented in Fig. 1 which shows the phylogenetic tree representation of the parental and fusant isolates, respectively. The evolutionary history was inferred using the Neighbor-Joining method [25]. The percentage of replicate trees in which the associated taxa clustered together in the bootstrap test (1000 replicates) is shown next to the branches [22]. Branches corresponding to partitions reproduced in less than 50\% bootstrap replicates were collapsed. The evolutionary distances were computed using the p-distance method [26] and are in the units of the number of base differences per site. The sum of branch lengths was calculated as 0.62235915. Parent and selected fusants were identi-

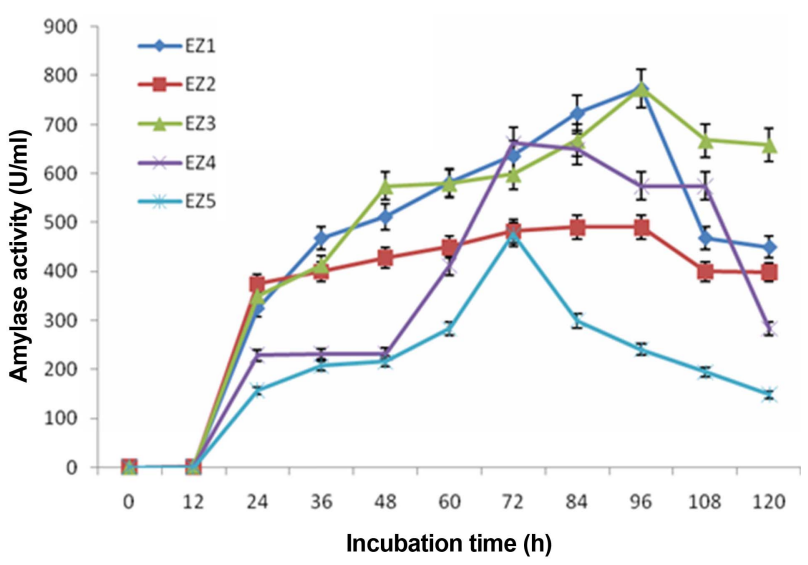

Fig. 2. Effect of incubation period on amylase production by parent and fusant Aspergillus spp.

fied as Aspergillus flavus (parent TA and fusant T5) and Aspergillus tamarii (parent TC, fusant $\mathrm{T} 13$ and T14). The sequences were submitted to the GenBank MH836320 and identified as Aspergillus sp. strain TMOD 01.

\section{Effect of incubation period}

The results illustrated on Fig. 2 shows the gradual increase in amylase activities of parent isolates after $24 \mathrm{~h}$ of incubation. While increase in amylase activities of enzymes from fusants T13 and T14 (EZ4 and EZ5) reached a peak after $72 \mathrm{~h}$ and on further incubation, there was a decline. Enzymes from parent isolates and fusant T5 (EZ1, EZ2 and EZ3) respectively showed peak of activities $(737.87 \mathrm{U} / \mathrm{ml}, 490.82 \mathrm{U} / \mathrm{ml}$ and $780.77 \mathrm{U} / \mathrm{ml})$ after $96 \mathrm{~h}$ after which a decline was observed on further incubation. This result shows that for all isolates stud-

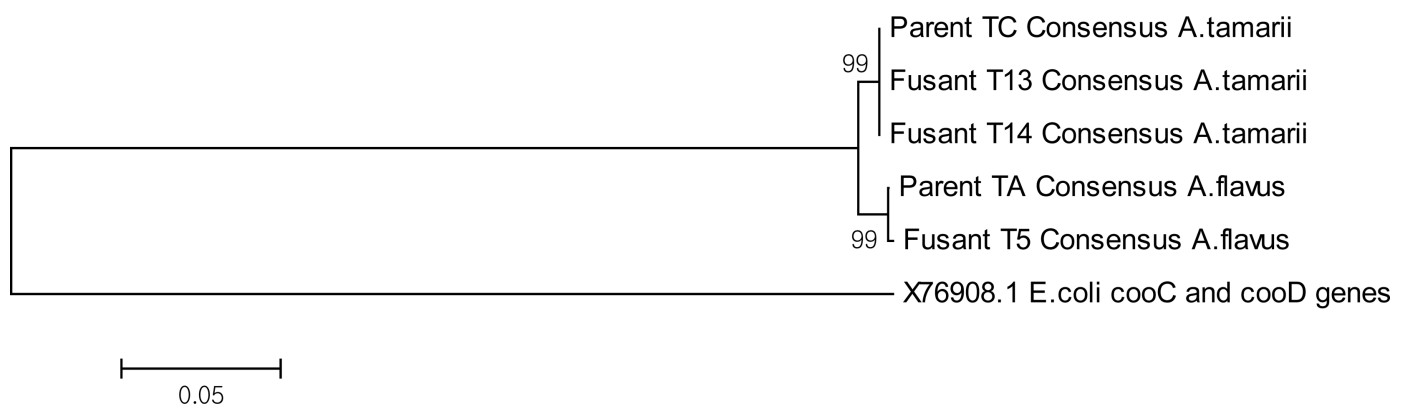

Fig. 1. Phylogenetic tree showing diversity of the 5.8S-ITS region sequences and the evolutionary relationship of taxa of parental and selected fusants. Fungi 1-5; TA, TC, T5, T13 and T14 respectively. Note: The evolutionary history was inferred using the Neighbor-Joining method. The optimal tree with the sum of branch length $=0.62235915$ is shown. The analysis involved 5 nucleotide sequences. Codon positions included were $1 s t+2 n d+3 r d+$ Noncoding. All ambiguous positions were removed for each sequence pair. There were a total of 568 positions in the final dataset. Evolutionary analyses were conducted in MEGA6. 
Table 2. Analysis of variance (ANOVA) for response surface model for amylase activity.

\begin{tabular}{lccccc}
\hline \multicolumn{1}{c}{ Source } & Sum of squares & Df & Mean square & F value & p-value Prob> F \\
\hline Model & $6.866 \mathrm{E}+005$ & 15 & 45775.83 & 4.28 & $<0.0001$ \\
A-Temperature & 4570.56 & 1 & 4570.56 & 0.43 & 0.5154 \\
B-pH & 38300.86 & 1 & 38300.86 & 3.58 & 0.626 \\
C-Enzyme & $3.940 \mathrm{E}+005$ & 4 & 98494.74 & 9.21 & $<0.0001$ \\
AB & 229.46 & 1 & 2289.46 & 0.21 & 0.6450 \\
AC & 70327.30 & 4 & 17581.83 & 1.64 & 0.1730 \\
BC & $1.772 \mathrm{E}+005$ & 4 & 44292.56 & 4.14 & 0.0046 \\
Residual & $7.377 \mathrm{E}+005$ & 69 & & & \\
Cor Total & $1.424 \mathrm{E}+006$ & 84 & & & \\
\hline
\end{tabular}

Standard Deviation = 103.40; Mean = 864.66; R- Squared = 0.4821;Adj R- Squared = 0.3695; Pred R- Squared = 0.2729; Adeq Precision $=11.626$.

ied, amylase activities increased linearly until certain points of decrease for individual enzyme types studied.

\section{Effect of the model parameters on amylase activities of} parents and selected fusants of Aspergillus

Table 2 shows the experimental runs generated by the RSM while the analysis of variance (ANOVA) of the significant model terms, which showed the low $\mathrm{p}$-values, high determination coefficients (R-Squared) and high values of adjusted determination coefficient (Adj RSquared), is described in Table 3. The low p-value obtained indicated that the model accurately represented the relationship between response and variables. The Model F-value (variation between sample means) of

Table 3. Optimized amylase activity obtained for optimum levels of $\mathrm{pH}$, temperature and enzyme.

\begin{tabular}{cccccc}
\hline Number & $\begin{array}{c}\text { Temperature } \\
\left({ }^{\circ} \mathrm{C}\right)\end{array}$ & $\mathrm{pH}$ & Enzyme & $\begin{array}{r}\text { Activity } \\
(\mathrm{U} / \mathrm{ml})\end{array}$ & Desirability \\
\hline 1 & 40.00 & 4.00 & $\mathrm{EZ3}$ & 1055.17 & ${ }^{*} 0.816$ \\
2 & 40.15 & 4.00 & $\mathrm{EZ3}$ & 1054.79 & 0.815 \\
3 & 41.00 & 4.00 & $\mathrm{EZ3}$ & 1052.61 & 0.813 \\
4 & 42.75 & 4.00 & $\mathrm{EZ3}$ & 1048.12 & 0.806 \\
5 & 40.00 & 4.00 & $\mathrm{EZ2}$ & 972.832 & 0.705 \\
6 & 80.00 & 8.00 & $\mathrm{EZ4}$ & 964.165 & 0.693 \\
7 & 80.00 & 8.00 & $\mathrm{EZ5}$ & 944.371 & 0.667 \\
8 & 77.99 & 8.00 & $\mathrm{EZ5}$ & 940.156 & 0.661 \\
9 & 80.00 & 7.17 & $\mathrm{EZ5}$ & 938.783 & 0.659 \\
10 & 40.00 & 4.00 & $\mathrm{EZ1}$ & 923.182 & 0.638 \\
11 & 40.00 & 4.25 & EZ1 & 920.313 & 0.634 \\
\hline
\end{tabular}

$\mathrm{KEY}^{*}$ - Selected combination.

Note; Enzyme 1-5; Enzyme from TA, TC, T5, T13 and T14 respectively.
4.28 implied that the model was significant. Similarly, values of "Prob > F" less than 0.0500 indicated that the model terms were significant. In this case C (Enzyme), $\mathrm{BC}$ ( $\mathrm{pH}$-Enzyme) are significant model terms that had a significant effect on amylase activity. Values greater than 0.1000 indicate the model terms are not significant. The "Pred (Predicted) R-Squared" of 0.2729 is in reasonable agreement with the "Adj R-Squared" of 0.3695. The adequate precision measured a ratio of 11.626 indicating an adequate signal.

\section{Effect of temperature and $\mathrm{pH}$ on amylase activities of par- ents and fusants Aspergillus spp}

The $3 \mathrm{D}$ response surfaces as shown in Fig. 3(A-E) are model graphs which are the graphical representation of the regression equation showing the combination effects of $\mathrm{pH}$ and temperature on activities of each amylase produced by parents TA and TC and selected fusants T5, $\mathrm{T} 13$ and T14, respectively in order to establish optimum values of variables such that response is maximized. As shown on the plots for fusants $\mathrm{T} 5$ and $\mathrm{T} 13$, increase in $\mathrm{pH}$ and temperature as individual variable factors resulted in an increase in amylase activity. However, keeping one of the variables constant, an increase in the other resulted in decrease in amylase activities with an exception in the plot for enzyme from parent TA (Fig. $3 \mathrm{~A})$, where a curvature occurred at some point indicating the possibility of an increase in amylase activity, beyond the experimental set up. As shown in Fig. 3E, amylase activity of enzyme from Fusant T14 increases with increase in temperature but decreases with increase in $\mathrm{pH}$. Also, keeping temperature constant, an 
A Design-Expert@ Softw are

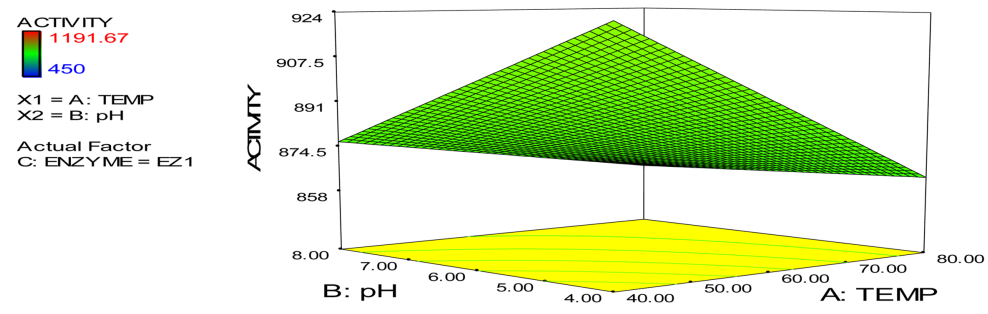

B Design-Expertø Softw are

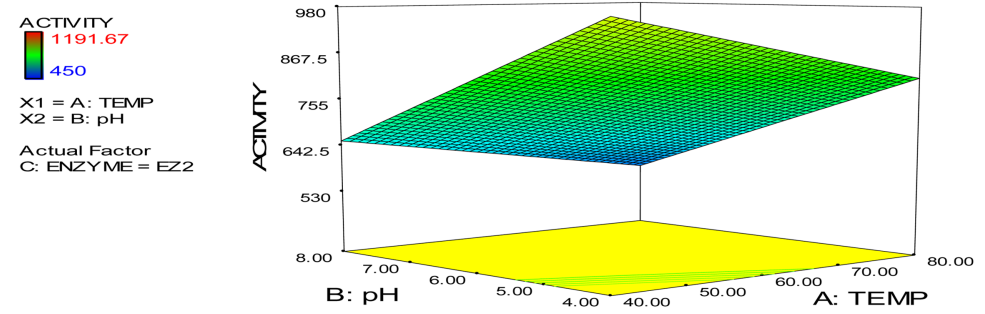

C Design-Expert@ Softw are

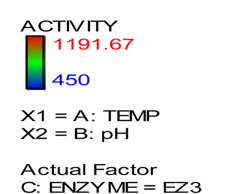

Actual Factor
C: $E N Z Y M E=E Z 3$

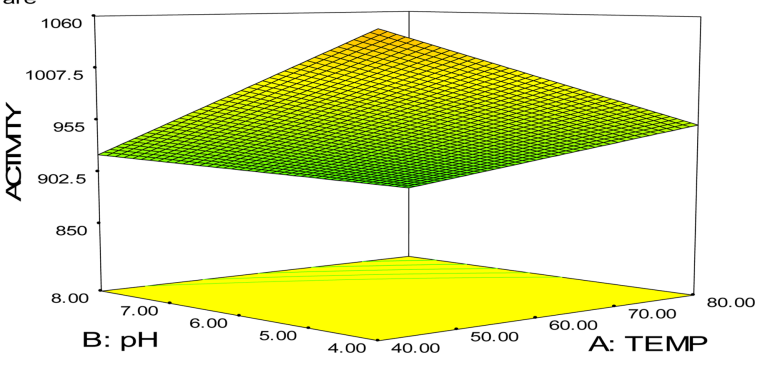

D Design-Expert@ Softw are

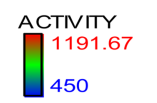

$\begin{array}{ll}X 1 & =A: T E M P \\ X 2=B: P H\end{array}$

Actual Factor

C: $E N Z Y M E=E Z 4$

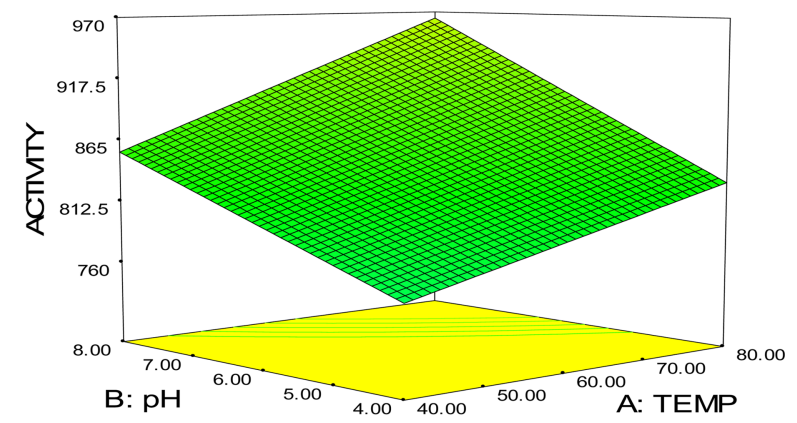

E Design-Expert® Softw are

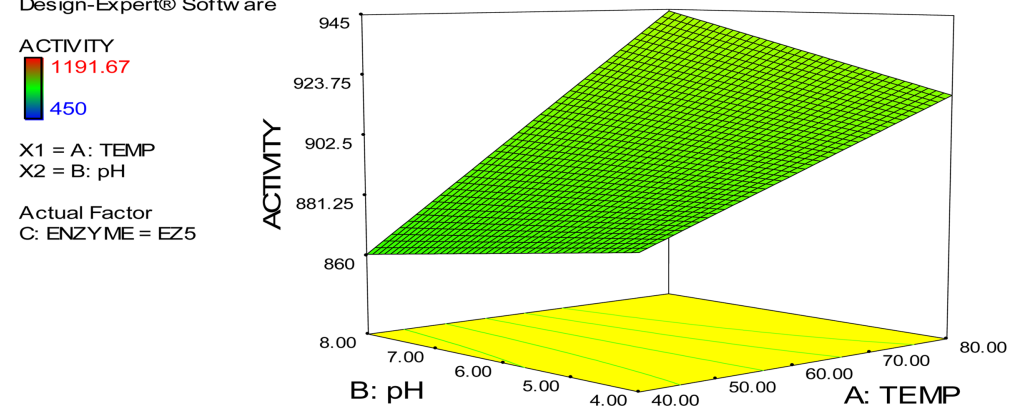

Fig. 3. 3D response surface plot showing effect of temperature and pH on amylase activity of parent, TA (A), TC (B), and fusants T5 (C), T13 (D), and T14 (E). 
increase in $\mathrm{pH}$ resulted in decreased enzyme activity. While low $\mathrm{pH}$ favoured amylase activities of parents, TA, TC and fusant T5, optimum activity was achieved at high $\mathrm{pH}$ for enzymes from fusants, T13 and T14.

\section{Optimization of pH and temperature for amylase activi-} ties of enzymes from parents and fusants Aspergillus spp.

Optimized amylase activities obtained for optimum levels of $\mathrm{pH}$, temperature and type of enzymes are shown in Table 3. Amylase activity was observed to be highest in EZ3 (1055.17 U/ml) which is enzyme from fusant $\mathrm{T} 5$ at a $\mathrm{pH}$ of 4 and temperature of $40^{\circ} \mathrm{C}$ while the least activity (920.313 U/ml) was observed in EZ1 which is enzyme from Parent, TA at a temperature of $40^{\circ} \mathrm{C}$ and $\mathrm{pH} 4.25$.

\section{Effect of amylases from parent and fusant Aspergillus spp on starch hydrolysis}

This is illustrated in Fig. 4(A-E). Glucose production was predominant over other ribose sugars present in the

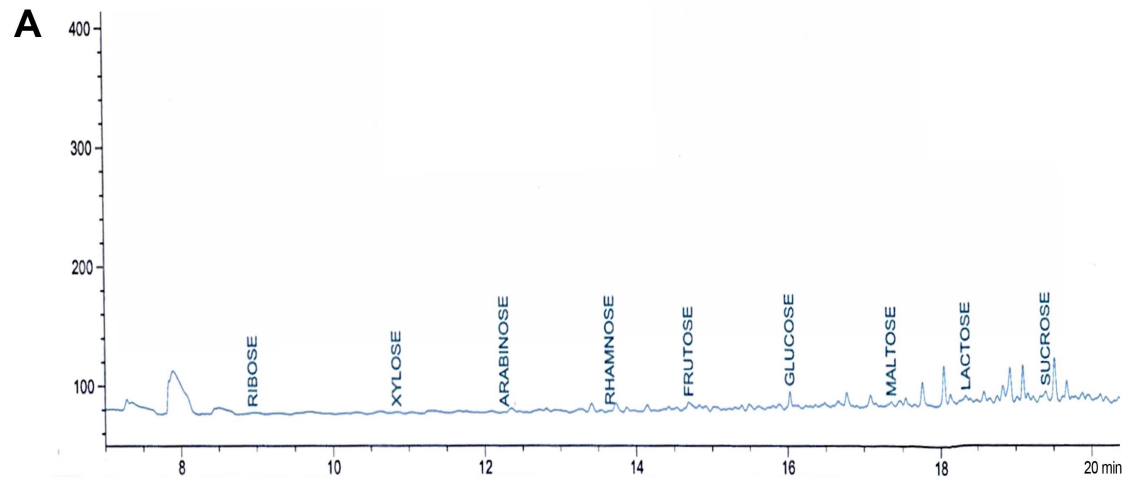

B
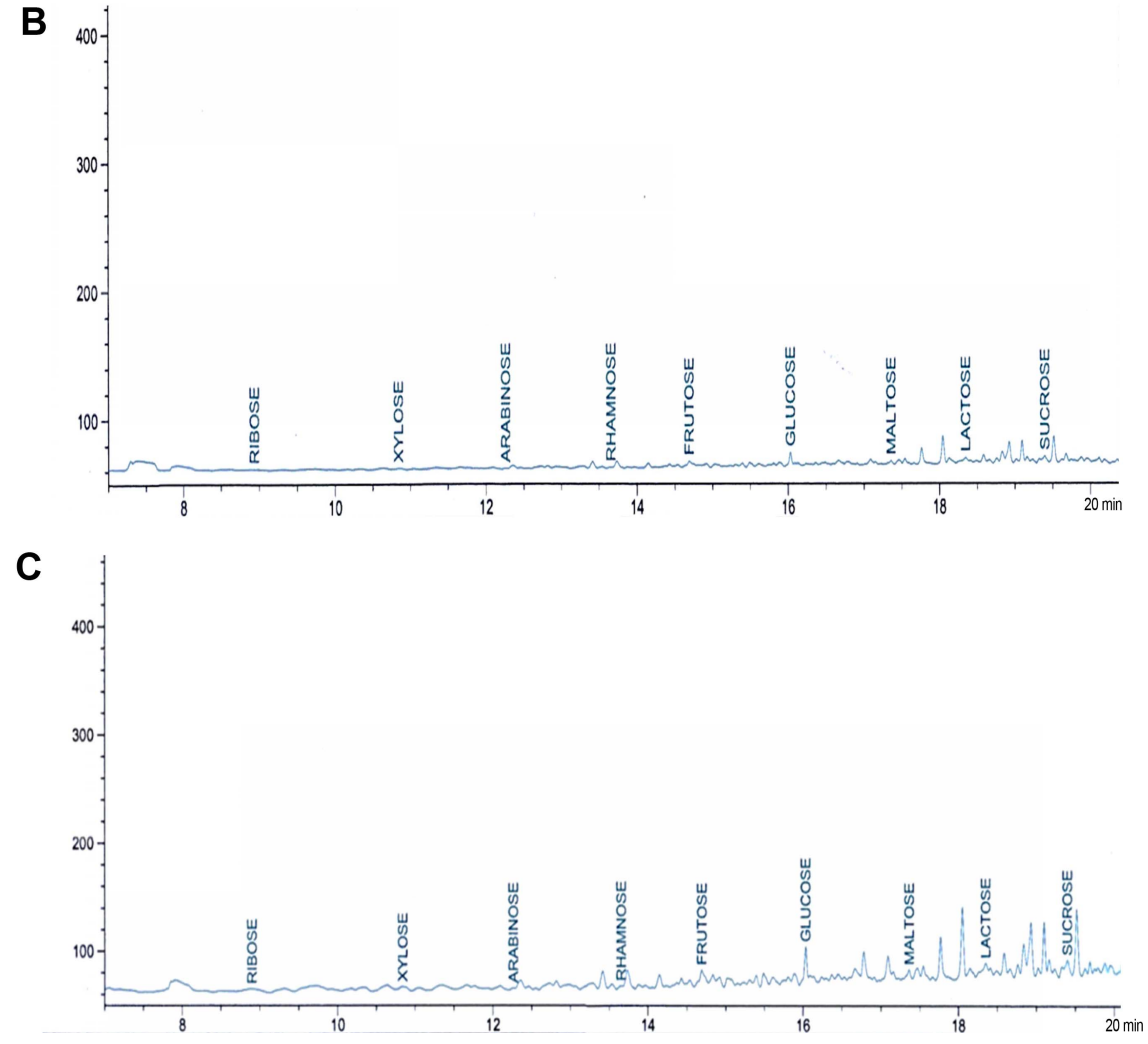

Fig. 4. Chromatogram of samples obtained from hydrolysis of starch under predicted optimum pH and temperatures by parent, TA (A), TC (B) and fusants T5 (C), T13 (D) and T14 (E). 

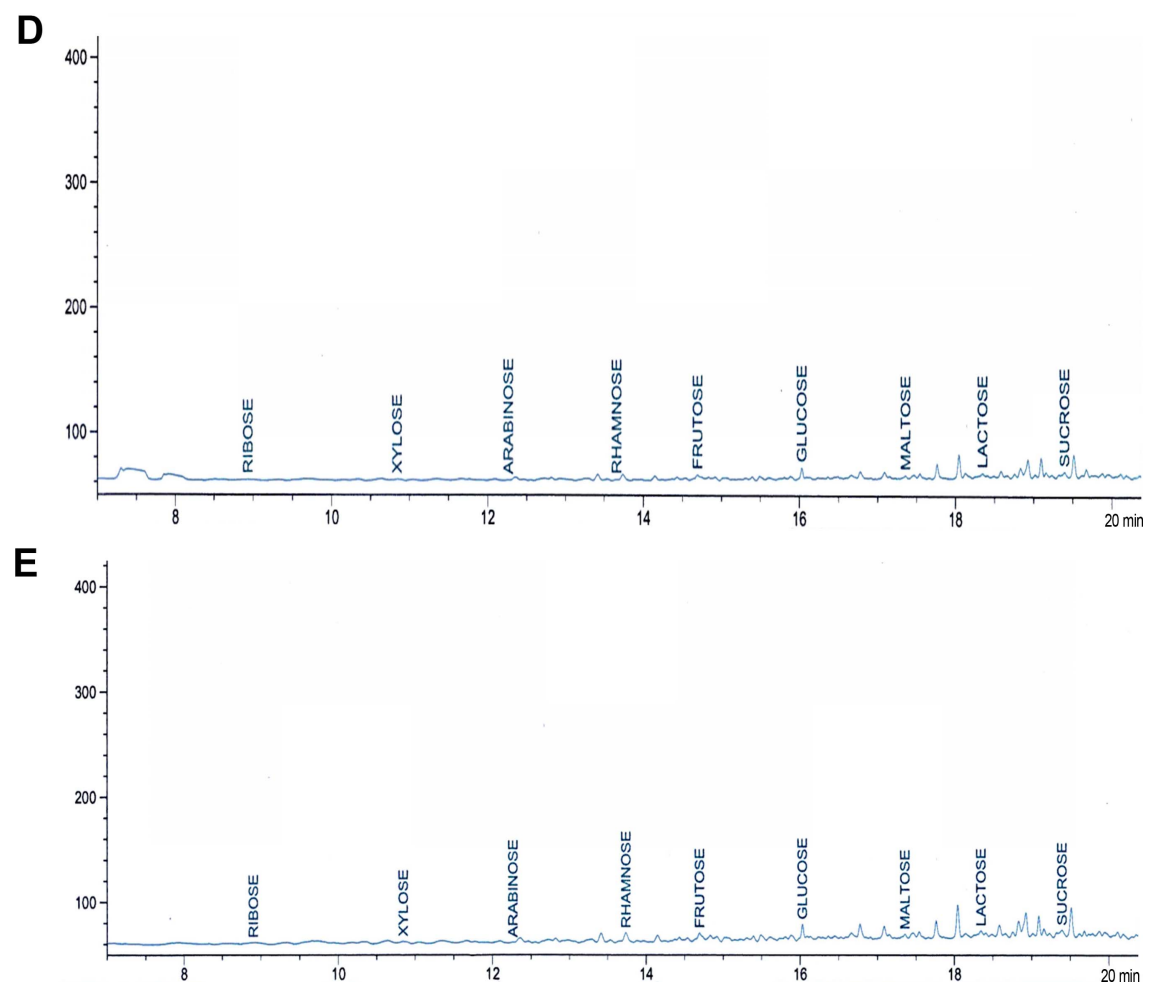

Fig. 4. Continued.

samples. Samples hydrolysed by enzymes from parent TA, parent TC, fusant T5, fusant T13 and fusant T14 are designated as A, B, C, D and E, respectively. Glucose production was least in Sample B $(1.1018 \mathrm{~g} / 100 \mathrm{ml})$ and highest in Sample C (1.6518 g/100 ml).

\section{Discussion and Conclusion}

Analysis of the sequences generated from the amplification of the ITS regions of the parent and fusant strain suggests trace occurrence of genetic recombination in the fusants, especially T5, as observed in the slight variation in the branch lengths of the phylogenetic tree representation. This likely genetic recombination occurs when cell fusion is followed by nuclear fusion between the protoplasts of the two isolates being fused [28]. The variations observed in amylase activities of fusants at the range of temperature and $\mathrm{pH}$ studied could have been made possible by certain additions, duplications or deletions in the genes responsible for amylase activity.

Regenerated fusants from the Aspergillus spp were selected based on the individual improved amylase activities at high and room temperatures, over the parental strains. This ability is of great industrial importance. Amylases that are active at room temperatures have great potentials in digesting raw starch as they will save costs that would have been incurred in the process of gelatinization of starch with the conventional starch hydrolysis. One of the fusants designated, T5 showing the highest activity of $920 \mathrm{U} / \mathrm{ml}$ at room temperature $(28$ $\pm 2^{\circ} \mathrm{C}$ ) can be recommended for such purpose unlike either of the parents. Primarily, the commercial application of amylases is the production of glucose syrups from starch which require enzymes with high activity at a high temperature. Fusant T5 still maintained a high activity $(966.67 \mathrm{U} / \mathrm{ml})$ at a temperature of $80^{\circ} \mathrm{C}$ but higher activities observed in fusants T14 (1012.16 U/ml) and T13 (1011.11I U/ml) makes them preferred options to fusant T5 and both Parents TA (A. flavus) and TC (A. tamarii). When carried out at high temperatures, enzymatic reactions have increased reaction rates and decreased contamination risk. Fusant T5 was more stable at a wider range of temperature than either of the parents or other selected fusants and thus most suitable 
for industrial purposes. It had been reported in previous research works that $76 \%$ of maximum activities of fungal glucoamylases were lost at high temperatures [23, 29, 30]. However, amylases produced by fusants T13 and $\mathrm{T} 14$ in the present research maintained high activity at high temperature. This agrees with the results obtained with glucoamylase produced by a mutant strain of $R h i$ zopus oligosporous SK5 showing optimum enzyme activity at a temperature of $80^{\circ} \mathrm{C}$ [6]. There is also a report on a strain of Aspergillus flavus having an optimum temperature of $70^{\circ} \mathrm{C}$ [31]. The results obtained from this study on the effect of $\mathrm{pH}$ on enzyme activities of parent and the selected fusantts agree with most of the previous researches, that amylases are active over a range of pH 4-8 [23, 31, 32]. Optimum pH of 4 observed for enzyme activity of amylase produced by fusant, T5 is similar to the observations Ajayi and Fagade [33] on the effect of $\mathrm{pH}$ on amylase from Bacillus sp. Others have also reported acidic optima $\mathrm{pH}$ for amylases from $A$. niger [34-36]. It has been observed that glucoamylases are active at acidic $\mathrm{pH}$ values. In contrast to this, amylase from fusant T14 in this study showed increased activity with increasing $\mathrm{pH}$ and particularly having an optimum $\mathrm{pH}$ of 8 . This property of the enzyme can be exploited for its industrial application in the making of detergents. Bacterial amylases having alkaline $\mathrm{pH}$ have been reported by different researchers [37, 38]. Studies on the effect of $\mathrm{pH}$ on $\alpha$-amylase from $A$. niger JG124 which gave a maximum enzyme yield of $75 \mathrm{U} / \mathrm{mg}$ at $\mathrm{pH}$ 9.5 has also been documented [39].

Determination of an optimum incubation time is important for maximum enzyme yield [15]. This is because maximum enzyme production is obtained only at a certain incubation time which allows for a steady growth rate of the culture [40, 41]. The present study also agrees with previous observations that enzyme production by each strain or isolate is highly specific to the growth rate of such isolates [40]. Amylases studied in the present work were observed to have shorter optimum incubation periods ( $72 \mathrm{~h}$ and $96 \mathrm{~h}$ ) compared a previous research works by $[12,42]$ where maximum amylase production was achieved at $120 \mathrm{~h}$ of incubation. A study on amylases produced by certain strains of Aspergillus reported a maximum incubation period for amylase production, at $72 \mathrm{~h}$ [40]. This finding is at par with the results obtained in this study on amylases pro- duced by fusants T13 and T14 (EZ3 and EZ4, respectively). Researchers have attributed the decline observed in amylase production on further incubation beyond the optimum time, to a possible depletion of essential nutrients for enzyme production and growth and or the accumulation of toxic metabolic products in the growth medium $[12,42]$. The variations in the optimum incubation period and also rate of decline in amylase production beyond the optimum incubation period could be an impact of the protoplast fusion technique employed in this study on the amylolytic properties of Aspergillus spp. However, this can only be confirmed by further investigtaions in future studies.

The low $p$-value obtained from the analysis of variance of data from the optimization of amylase activity using Response Surface 2FI model, indicates that the model accurately represented the relationship between response and the variables. The derived equations in terms of coded factors can be used to make pedictions about the response for given levels of each factor. By default, the high levels of the factors are coded as +1 and the low levels of the factors are coded as -1 . The coded equation is useful for identifying the relative impact of the factors by comparing the factor coefficients. Moreover, the equations derived in tems of actual factors can also be used to make predictions about the response for given levels of each factor, where the levels will be specified in the original units for each factor. This equation however, cannot be used to determine the relative impact of each factor because the coefficients are scaled to accommodate the units of each factor and the individual intercepts are not at the centre of the design space. The adequtate precision (11.626) which measured the signal to noise ratio, was greater than 4, was desirable indicating an adequate signal. This ratio indicates the model can therefore be used to navigate the design space satisfactorily [43-45]. Results of the optimization studies presents enzyme from Fusant T5 as the most preferred as compared to the parents and other selected fusants.

One approach to discriminate $\alpha$-amylase and glucoamylase is via the evaluation of their hydrolysis product. $\alpha$ Amylase action results in various kind of oligomeric sugars whilst glucoamylase hydrolysis product is predominantly glucose (monomers) [46]. Results obtained from the analysis of type of sugars present in samples obtained from the hydrolysis of cassava starch $(5 \% \mathrm{w} / \mathrm{v})$ 
by amylases (1\% w/v) produced in this study showed that glucose was the most abundant ribose sugar. The production of glucose from a one-step hydrolysis of cassava starch in this study indicates the presence of $\alpha$ amylase in the enzyme used for hydrolysis as glucoamylases can only act on liquefied starch and not directly on starch granules. Variation observed in the amount of glucose obtained in each sample, is a function of the presence of $\alpha$-amylase and glucomylases in varying concentrations.

In conclusion, this study describes the significance of the protoplast fusion technique as a tool for the development of improved amylases from Aspergillus species. Results of optimization studies and starch hydrolysis indicate an enhanced amylase production in fusants over the parent isolates. It can be concluded therefore that protoplast fusion is an inexpensive technique to achieve strain improvement for industrial applications.

\section{Acknowledgment}

The authors acknowledge the staff of the Virology Unit of the Institute of Tropical Agriculture (IITA), Ibadan, Nigeria, where the molecular characterization of the isolates was carried out.

\section{Conflict of Interest}

The authors have no financial conflicts of interest to declare.

\section{References}

1. Ratnasri PV, Lakshmi BKM, Devi KA, Helmalatha KPJ. 2014. Isolation, characterisation of Aspergillus fumigatus and optimization of cultural conditions for amylase production. Int. J. Res. Eng. Technol. 3: 457-463.

2. Abe J, Nukajoma R, Nagano H, Hijkeri S. 1988. Properties of the raw starch digesting amylase of Aspergillus spp. k-27: synergistic action of glucoamylase and $\alpha$-amylase. Carbohydr. Res. 75: 85-92.

3. Gupta R, Gigras P, Mohapatra H, Goswami VK, Chauhan B. 2003. Microbial amylases: A biotechnological perspective. Process Biochem. 38: 599-616.

4. Sanraj P, Stella D. 2013. Fungal Amylase- A Review. Int. J. Microbiol. Res. 4: 203-211.

5. Stamford TLM, Stamford NP, Coelho LCBB, Araujo JM. 2002. Production and characterization of a thermostable glucoamylase from Streptosporangium spp. endophyte of maize leaves. Bioresour. Technol. 83: 105-109.

6. Kareem SO, Akpan I, Popoola TOS, Sanni L. 2014. Purification and characterisation of thermostable glucoamylase from Rhizopus oligosporous SK5 mutant obtained through UV radiation and chemical mutagenesis. Biokemistri 26: 9-24.

7. Enyioha EJ, Ameh JB, Umoh VJ. 2004. Evaluation and enhancement of amylase production by local strains of Streptomyces sp. Nig. J. Microb. 18: 300-308.

8. Hanson EL, Howell CR. 2002. Biocontrol efficacy and other characteristics of protoplast fusants between Trichoderma koningii and T. virens. Mycol. Resour. 106: 321-328.

9. Savitha S, Sadhasivam S, Swaminathan K. 2010. Regeneration and molecular characterization of an intergeneric hybrid between Graphium putredinis and Trichoderma harzianum by protoplasmic fusion. Biotechnol. Adv. 28: 285-292.

10. Ahmed M, Berkly E. 2006. Gene transfer between different Trichoderma species and Aspergillus niger through intergeneric protoplast fusion to convert ground rice straw to citric acid and cellulase. Appl. Biochem. Biotechnol. 135: 117-132.

11. Hassan MM, El-Awady MA, Lakhani HN, El-Tarras AE. 2013. Improvement of biological control activity in Trichoderma against some grapevine pathogens using protoplast fusion. Life Sci. 10: 2275-2283.

12. Omoniyi MC. 2013. Optimization of $\alpha$-amylase and glucoamylase production from three fungal strains isolated from Abakaliki Ebonyi State. Euro. J. Exp. Biol. 3: 26-34.

13. Kasim EA. 1983. Effect of the physiological condition on alpha amylase and glucoamylase formation by selected strain of Aspergillus oryzae. Mikrobiologiia 53: 422-427.

14. Gupta A, Gupta VK, Modi DR, Yadava LP. 2008. Purification and characterization of $\alpha$-amylase from Aspergillus niger. Biotechnol. 7: 551-556.

15. Roheena A, Naeema S, Mehwish I, Shagufta N, Tehreema I. 2014. Optimization of cultural conditions for the production of alphaamylase Aspergillus niger (BTM-26) in solid state ferementation. Pak. J. Bot. 46: 1071-1078.

16. Bussamara R, Dall'Agno L, Schrank A, Fernandes KF, Vainstein MH. 2012. Optimal conditions for continuous immobilization of Pseudozyma hubeiensis (strain hb85a) lipase by adsorption in a packed-bed reactor by response surface methodology. Enzyme Res. 2012: 329178.

17. Manohar B, Divakar S. 2004. Applications of surface plots and statistical design to selected lipase catalyzed esterification reactions. Process Biochem. 39: 847-853.

18. Afshin E, Zaliha RN, Rahman RA, Ch'ng DHE, Basri M, Salle AB. 2008. A modelling study by response surface methodology and artificial neural network on culture parameters optimization for thermostable lipase production from a newly isolated Thermophilic geobacillus spp. strain ARM. BMC Biotechnol. 96: 8-15.

19. Kocher GS, Uppal S. 2013. Fermentation variables for the fermentation of glucose and xylose using Saccharomyces cerevisiae $Y$ 2034 and Pachyso lantannophilus Y-2460. Ind. J. Biotechnol. 10: 531-536.

20. Akpan I, Bankole MO, Adesmowo AM, Lantunde-Dada GO. 1999. Production of amylase by Aspergillus niger using rice bran and agricultural material. Trop. Sci. 39: 77-79. 
21. Akpan I, Adelaja FA. 2004. Production and stabilization of amylase preparations from rice bran solid medium. World. J. Microb. Biotechnol. 20: 47-50.

22. Felsenstein J. 1985. Confidence limits on phylogenies: An approach using the bootstrap. Evolution 39: 783-791.

23. Koc O, Metin K. 2010. Purification and characterization of a thermostable glucoamylase produced by Aspergillus flavus HBF34. Afr. J. Biotechnol. 9: 3414-3424.

24. Shaw R. 1969. Analysis of potato sugars by gas chromatography. Am. Potato J. 46: 201-213.

25. Saitou N, Nei M. 1987. The neighbor-joining method: A new method for reconstructing phylogenetic trees. Mol. Biol. Evol. 4: 406-425.

26. Nei M, Kumar S. 2000. Molecular evolution and phylogenetics. pp. 54-60. Oxford University Press, New York.

27. Tamura K, Stecher G, Peterson D, Filipski A, Kumar S. 2013. MEGA6: Molecular evolutionary genetics analysis version 6.0. Mol. Biol. Evol. 30: 2725-2729.

28. Singh S, Sharma V, Soni ML. 2011. Biotechnological application of industrially important amylase enzyme. Int. J. Pharma Bio Sci. 2: 486-496.

29. Pandey A. 1995. Glucoamylase research: An overview. Starch/ Starke 47: 439-445.

30. Takahashi T, Tsuchida Y, Irie M. 1978. Purification and some properties of three forms of glucoamylase from Rhizopus species. J. Biochem. 84: 1183-1194.

31. Gomes E, Souz SR, Grandi RP, Silva ED. 2005. Production of thermostable glucoamylase by newly isolated A. flavus. 1.1. and Thermomyces lanuginous A 13.3. Braz. J. Microbiol. 36: 75-82.

32. El-Abyad MS, El-Shanshoury AR, Hafez M. 1995. Purification and characterisation of the glucoamylase produced by a strain of Aspergillus flavus. Microbios. 80: 7-15.

33. Ajayi AO, Fagade OE. 2007. Heat activation and stability of amylases from Bacillus species. Afr. J. Biotechnol. 6: 1181-1184.

34. Uguru GC, Akinyanju JA, Sani A. 1997. The use of yam peel for growth of locally isolated Aspergillus niger and amylase production. Enzyme Microbiol. Technol. 23: 107-112.

35. Hernandez MS, Rodriguez MR, Guerra NP, Roses RP. 2006. Amylase production by Aspergillus niger in submerged cultivation on two wastes from food industries. J. Food Process Eng. 73: 93-100.

36. Mtidieri S, Souza Martinelli AH, Schrank A, Vainstein MH. 2006. Enzymatic detergent formulation containing amylase from Aspergillus niger: A comparative study with commercial detergent formulations. Bioresour. Technol. 97: 1217-1224.

37. Yamamoto M, Tanaka Y, Horikoshi K. 1972. Alkaline amylases of alkalophilic bacteria. Agric. Biol. Chem. 30: 1819-1823.

38. Forgarty WM, Kelly CT. 1979. Starch degrading enzymes of microbial origin. In: Bull AH (ed). pp 87-150. Progress in Industrial Microbiology, Elsevier, Amsterdam.

39. Varalakshmi KN, Kumudini BS, Nandini BN, Solomon J, Suhas R, Mahesh B. 2009. Production and characterization of $\alpha$-amylase from Aspergillus niger JGI 24 isolated in Bangalore. Pol. J. Microbiol. 8: 29-36.

40. Murali KC, Sasidhar P, Suresh C. 2010. Isolation and production of extracellular amylase from newly isolated Aspergillus species by submerged fermentation. Curr. Trends Biotechnol. Pharm. 4: 795800.

41. Gangadharan D, Sivaramakrishnan S, Madhavan KN, Pandey A. 2006. Solid culturing of Bacillus amyloliquefaciens for alpha amylase production. Food Technol. Biotechnol. 442: 269-274.

42. Farid MAF, Mohammed H, Shata AH. 2011. Amylase production from Aspergillus oryzae LS1 by solid-state fermentation and its use for hydrolysis of wheat flour. Iran. J. Biotechnol. 9: 267-274.

43. Tanyildizi MS, Ozer D, Elibol M. 2005. Optimization of $\alpha$-amylase production by Bacillus sp. using response surface methodology. Process Biochem. 40: 2291-2296.

44. Acıkel U, Ersan M, SağAcıkel Y. 2010. Optimization of critical medium components using response surface methodology for lipase production by Rhizopus delemar. Food Bioprod. Process $\mathbf{8 8}$ : 31-39.

45. Shabbiri K, Adnan A. 2011. Bio-statistically optimized production of lipases by Brevibacterium linens DSM 20158. World. Appl. Sci. J. 13: $1059-1066$.

46. Gasteiger E, Hoogland C, Gattiker A, Duvaud S, Wilkins MR, Appel RD. 2005. Protein identification and analysis tools on the ExPASy server, pp. 571-607. In: Walker JM, editor. The Proteomics Protocols Handbook, New York: Humana Press, 2005. 